Acta vet. scand. $1972,13,161-174$.

From the Institute of Medical Microbiology, University of Aarhus, Aarhus, and the State Veterinary Serum Laboratory, Copenhagen, Denmark.

\title{
MYCOPLASMOSIS: EXPERIMENTAL AND SPONTANEOUS INFECTIONS OF THE GENITAL TRACT OF BULLS
}

\author{
By \\ Henning Ernф and Erik Blom
}

ERN $\emptyset$, HENNING and ERIK BLOM: Mycoplasmosis: Experimental and spontaneous infections of the genital tract of bulls. Acta vet. scand. $1972,13,161-174$. - A strain of M. bovigenitalium was isolated from semen of a bull $(K)$ with chronic seminal vesiculitis. Using this strain a vesiculitis of the same type as found in bull $K$, characterized by simultaneous acute and chronic lesions, was induced experimentally in 2 bulls by direct inoculation into the vesicular glands. In the acute phase a marked infiltration of eosinophils was found in the interstitial tissues and alveoli whereas in the chronic phase fibrosis, lymphoid and epithelial hyperplasia were seen. Degeneration of vascular walls and connective tissue was common.

On inoculation into the testis of 3 bulls a chronic epididymitis and ampullitis were produced. The histological changes were of the same type as found in the vesicular glands of the 3 bulls with vesiculitis.

By indirect hemagglutination a specific and significant increase in serum antibody could be demonstrated. As the titers were low and the maximum titers were reached early, it will probably not often be possible to make an etiological diagnosis on the basis of serological evidence.

A comparative experiment employing the type strain (PG 11) of $M$. bovigenitalium was performed. A rise in antibody titer was seen, but neither clinical nor histological changes could be demonstrated.

bovine genital mycoplasmosis; seminal vesiculitis; eosinophilia.

Despite the eradication of brucellosis 15 years ago, several cases of seminal vesiculitis in young bulls are found in Denmark every year. Some of the cases are characterized by being abacterial and by the occurrence of pus cells in semen over a prolonged period of time. It is well known that mycoplasmas can be regularly cultured from semen samples, and one must conclude 
that in general these microorganisms behave as commensals in the genital tract of bulls. This fact does not exclude the possibility that mycoplasmas at times can cause inflammation of the genital tract, as a result of either predisposing circumstances or occurrence of specific pathogenic strains.

On this basis, the State Veterinary Serum Laboratory initiated a search for mycoplasmas in semen samples containing pus cells. Mycoplasmas were isolated from 5 bulls, and 1 of these animals, $\mathrm{K}$, was purchased for further examination; a series of experimental inoculations with this particular strain, " $K$ ", identified as M. bovigenitalium, were conducted.

The experiments were primarily intended to elucidate the basic question whether strain " $K$ " was able to induce lesions similar to those found in bull K (Blom \& Ern $\varnothing$ 1967). Furthermore, it was of interest to know, if an experimental inoculation was influenced by a preceding spontaneous or induced preputial infection with $M$. bovigenitalium. Finally, an experiment was devised to investigate, whether growth factors or preformed toxins which might have been present in the cultures used in the first experiments were necessary for induction of lesions; also serologic responses in bulls inoculated with either the type strain of M. bovigenitalium (PG 11) or the " $K$ " strain, were compared. The former strain was expected to be non-pathogenic (Ern $\phi$ 1972).

\section{MATERIALS AND METHODS}

\section{Bulls}

a. The bull K, Danish Friesian breed, was 1 year old when pus in the semen was first found.

b. Exps. 1 and 2. Bulls 89 and 90, twins, of Red Danish breed, 19 months old. Mycoplasmas not isolated before inoculation.

c. Exp. 3. Bull D, Red Danish breed, 2 years old, used for natural service. Before inoculation M. bovigenitalium was isolated from preputial and semen samples.

d. Exp. 4. Bull 57, Red Danish breed, 1 year old. Mycoplasmas not isolated before inoculation.

e. Exps. 5 and 6. Bulls 181 and 182, twins, Danish Friesian breed, $1 \frac{11 / 2}{2}$ years old. Mycoplasmas not recovered before inoculation.

Isolation and propagation of mycoplasmas

Culture methods and mediums for isolation and propagation of mycoplasmas were similar to those previously reported (Ernø et al. 1967). 
Clinical examination and examination of semen

All animals were examined clinically before inoculation and at least once a week p.i. Culturing for bacteria and mycoplasmas was performed once a week, as were observations on the appearance of ejaculates, admixture of cells, and quality of sperm. Hemograms were performed in bulls 181 and 182 only.

\section{Examination post mortem}

The genital organs were examined macroscopically and samples were taken as required for histologic and microbiological examinations.

\section{Serological examination}

The antibody response was determined by the indirect hemagglutination test using fresh, tanned sheep erythrocytes (Krogsgaard-Jensen 1971).

\section{Bull $\boldsymbol{K}$}

\section{EXPERIMENTS AND CASE REPORTS}

\section{a. Clinical examination and examination of semen}

Clinical examination revealed that the left epididymis and vesicular gland were absent*. The right vesicular gland was of normal size but somewhat firm. Ten ejaculates collected during the last 2 months before slaughtering were of varied quality, often with admixture of pus floccules. All samples had an abnormally high $\mathrm{pH}$ $(>7.0)$ and a low content of dry matter $(<3 \%)$. Sperm morphology was normal. Mycoplasmas were shed intermittently and isolated only twice. The last isolation was made a week before slaughtering. At this time the semen contained $10^{6}$ colony forming units (c.f.u.)/ml; bacteria could not be demonstrated as a cause of this chronic vesiculitis. The bull was slaughtered after a period of 17 weeks.

\section{b. Examination post mortem}

The left vesicular gland and epididymis were practically missing. Left ampule was less developed than usual, being only $6 \mathrm{~cm}$ in length. The right vesicular gland was very firm; the cut surface was brownish and dry, and only rather dry drops of secretion could be squeezed from the acini. Histopathological examination revealed lesions in the right vesicular gland only. Areas were found with chronic lesions consisting of fibrosis, stagnation of secretion, atrophy and desquamation of epithelial cells. In other areas the pathologic changes were acute with extensive infiltrations of eosinophilic granulocytes in the interstitia and alveoli, interstitial accumulations of plasma cells, histiocytes and lymphocytes (Fig. 1). Leucocytes with eosinophilic granules had a somewhat varied appearance, a few being large cells with a

* Diagnosis: Segmental aplasia of the Wolffian duct on the left side, a congenital defect described by Blom \& Christensen (1951). 
round pale nucleus; others were similar in size to lymphocytes with a small dark nucleus. However, most cells did have the characteristic appearance of eosinophils, although the cytoplasmic granules were often rather poorly stained and the nucleus often hypersegmented. Intraepithelial occurrence of eosinophils was common (Fig. 2). The alveolar epithelium was at times hyperplastic and folded. Some of the lumina were filled with acidophilic or basophilic amorphous material mixed with cells, occasionally slightly calcified. Focal areas with hyaline degeneration of the connective tissue were seen.

Mycoplasmas were cultured from the preputial cavity but not from the ampullae, testis or vesicular gland. Bacteriological examination was negative. A serum titer of 16 was found in the indirect hemagglutination test (Table 1).

T a b l e 1. Final serum titers of bulls infected with M. bovigenitalium as measured by indirect hemagglutination.

\begin{tabular}{lrcc}
\hline Bull & \multicolumn{2}{c}{ A n t ig e n } & \multirow{2}{*}{$\begin{array}{c}\text { Weeks after } \\
\text { infection }\end{array}$} \\
\cline { 2 - 3 } & strain K & strain PG 11 & $>17$ \\
\hline K & 16 & 8 & 3 \\
89 & 16 & 2 & 8 \\
90 & 128 & 32 & 8 \\
D & 16 & 8 & $32+13$ \\
$57^{\star}$ & 2048 & 4096 & 8 \\
181 & 64 & 8 & 8 \\
182 & 64 & 64 & 8 \\
\hline
\end{tabular}

* Bull 57 was inoculated in the preputial cavity and reinoculated 32 weeks later in testis.

\section{Experiment 1. Bull 89}

The animal was inoculated in the vesicular glands through the rectal wall (Christensen 1948). A total of $12 \mathrm{ml}$ of a 72-hr. old uncloned culture of strain " $K$ " with 105 viable cells per ml was deposited in the cranial, central and caudal parts of both glands. The bull was slaughtered 3 weeks p.i.

\section{a. Clinical examination and examination of semen}

On the 3rd day the right vesicular gland was enlarged to about double size while the left one did not appear enlarged until the 14th day. At this time both glands were firm and hard. Gray-brown semen with clots of pus was collected on the 3rd day. Pus admixture continued till slaughtering on the 23rd day. Mycoplasmas were recovered from semen on 4 occasions, but the sample taken the day before slaughtering was negative. 


\section{b. Examination post mortem}

All genital organs appeared normal except for the vesicular glands. The left one was firm and almost twice as large as normal. The cut surface yielded a creamy yellow secretion. The right vesicular gland was also firm, about $50 \%$ enlarged and had hemorrhagic and pusfilled foci subcapsularly. The cut surface was dry and brownish, with only a sparce secretion present as honey-like drops. Histological examination revealed pathological changes of only the vesicular glands. The lesions were of the same character as those found in the vesicular gland of bull $\mathrm{K}$, but the lymphocytic infiltration was more pronounced, and so were the degenerative and proliferative changes of epithelial cells (Fig. 3). The number of eosinophilic granulocytes and plasma cells was less than seen in bull $K$. It was typical for this case also that some areas appeared almost normal, whereas the structure of other areas was blurred with inter-alveolar fibrosis, stagnation of secretion, atrophy and rupture resulting in interalveolar connections (Fig. 4). Hyaline degeneration of the walls of blood vessels was seen. Occasionally, epithelial cells with coarsely granular cytoplasm were found, at times even containing inclusion-body-like structures.

Mycoplasmas were recovered from the vesicular glands, the ampules and the prepuce. A titer of 16 was found in serum by the indirect hemagglutination test (Table 1).

\section{Experiment 2. Bull 90}

The animal was infected in the left testis, proximally and distally, with a total of $6 \mathrm{ml}$ of the culture used in Exp. 1. The bull was slaughtered after 2 months of observation.

\section{a. Clinical examination and examination of semen}

After 1 month the left ampule was firm and slightly enlarged. Two weeks later a hard swelling, the size of a hazel-nut, appeared in the caput epididymidis. On the 22nd day, semen with a heavy admixture of pus cells was collected, and this continued until slaughtering 2 months p.i. Mycoplasmas were recovered after 1 week of observation and all subsequent samples were positive with 1 exception, i.e., the sample taken 3 weeks p.i. The c.f.u. per ml of semen 1 month p.i. was 108. This level was kept for 2 weeks, when the count decreased to $10^{3}$ c.f.u. per ml.

\section{b. Examination post mortem}

Macroscopic changes were found in the left testis, epididymis and ampulla. The tunica vaginalis communis was edematous, yellowish, with fibrous adhesions between the 2 layers laterally. The testis itself was strongly distended and edematous. Microscopically a severe lymphoid hyperplasia was found in the mediastinum testis and in the interstitial tissues of the adjacent seminiferous tubules, but apart from this only a few aggregations of round cells were seen in the testis 
itself. In the epididymis, lesions of a different type were seen. The caput epididymidis was the site of chronic changes: fibrosis and formation of granulomatous tissue, lymphoid hyperplasia, atrophy and desquamation of epithelial cells liberated to the lumina, at times occluded. Many plasma cells were present, often in a periductular arrangement. Severe lesions occurred in the corpus epididymidis: abscess formation, edema and infiltrations of cells in the capsular and pericapsular tissue. The infiltrations were generally associated with blood vessels, showing endothelial hyperplasia. In the cauda, acute changes were present in the form of necrosis, edema, hemorrhages and cellular infiltrations. The interstitial cells were of the lymphocytic and histiocytic type; whereas the intraductular cells were mainly eosinophils with regular granules or with an edge of eosinophilic cytoplasm. The nuclei were usually round, a few were lobulated. Many blood vessels revealed degeneration of the walls (Fig. 5). In the left ampulla hyperplasia of epithelial cells, fibrosis and focal accumulations of lymphocytes were seen as well as intraepithelial and interstitial infiltration of eosinophils (Fig. 6). Mycoplasmas could be recovered from the left testis, epididymis, ampulla and the preputial cavity. A titer of 128 was found in the serum by the indirect hemagglutination test (Table 1 ).

\section{Experiment 3. Bull D}

This animal was inoculated in the left testis with $5 \mathrm{ml}$ of a 72-hr. old uncloned culture of strain " $K$ " having 108 c.f.u. per $\mathrm{ml}$ and was slaughtered after a period of observation of 2 months.

\section{a. Clinical examination and examination of semen}

As in bull 90 a swelling appeared in the caput epididymidis 6 weeks p.i.; whereas pus cells appeared only 1 week prior to this but in great numbers, as the semen contained $10^{8}$ cells per ml. The shedding of mycoplasmas was intermittent, only every second of 8 samples being positive.

\section{b. Examination post mortem}

Macroscopically, an induration of hazel-nut size with central suppuration was found in the left caput epididymidis. Histologically, the lesions in testis, epididymis and ampulla were as described in bull 90. Ductular necrosis and lymphoid hyperplasia are demonstrated in Fig. 7.

Mycoplasmas were isolated from the left ampule, caput epididymidis, testis, prepuce and from the pus found in the caput epididymidis. A titer of 16 was found in serum by the indirect hemagglutination test 8 weeks p.i. (Table 1), whereas no reaction was found 3 weeks p.i. 
Henning Ernф and Erik Blom:

Mycoplasmosis: Experimental and Spontaneous Infections of the Genital Tract of Bulls.

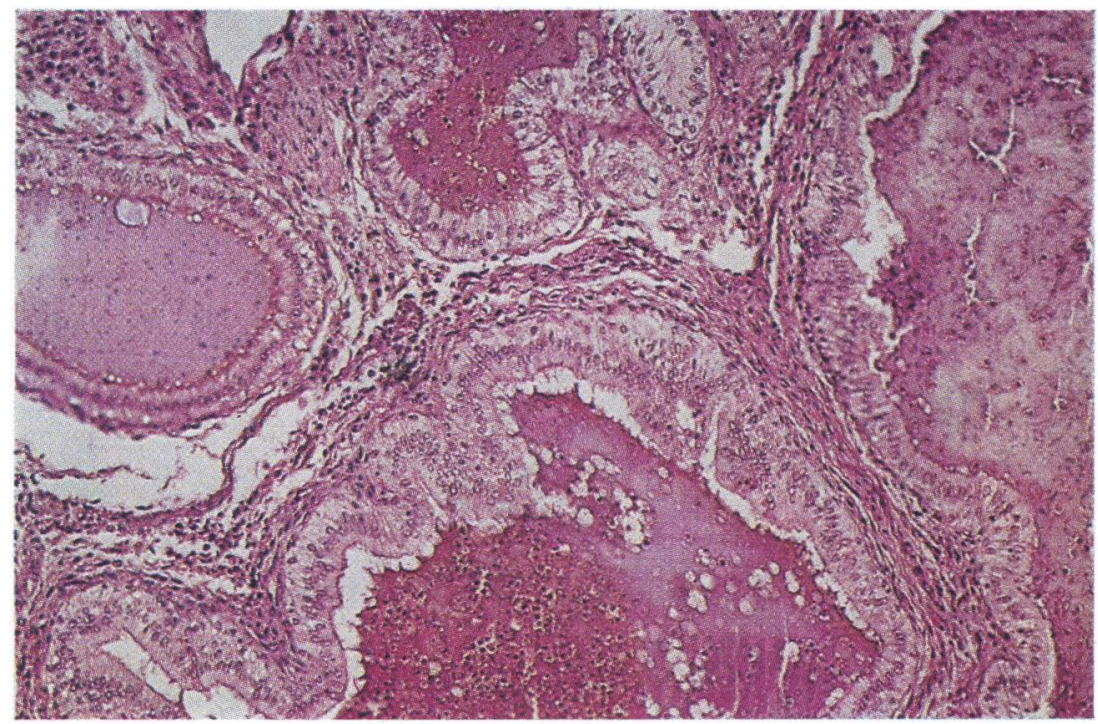

Fig u r e 1. Bull K. Spontaneous seminal vesiculitis. Intraalveolar accumulations of eosinophils (compare Fig. 2); interalveolar infiltrations of mononuclear cells and eosinophils (compare Fig. 2). Epithelial hyperplasia. (HE, $106 \times)$.

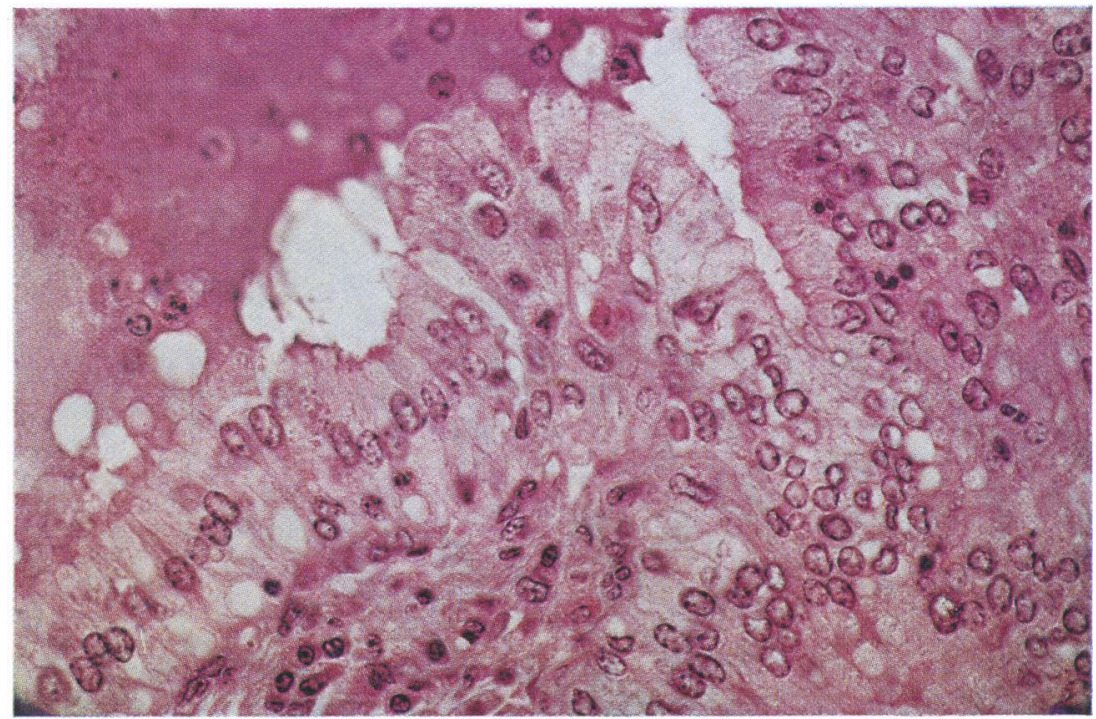

Figu re 2. Higher magnification of Figure 1. Interalveolar, intraepithelial and intraalveolar eosinophilic granulocytes. Interalveolar plasma cells and lymphocytes. (HE, $424 \times$ ). 


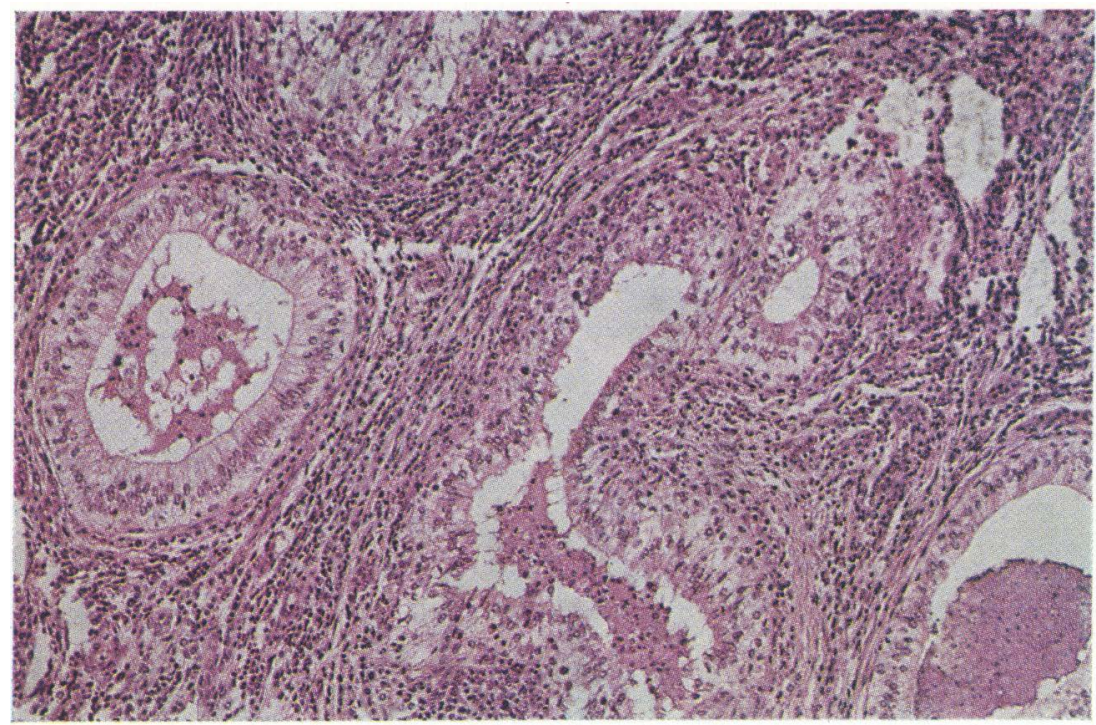

F i g u r e 3. Bull 89. Induced seminal vesiculitis. Intraalveolar accumulations of cells. Degeneration and proliferation of epithelial cells. Severe interstitial infiltration of mononuclear cells.

$(\mathrm{HE}, 106 \times)$.

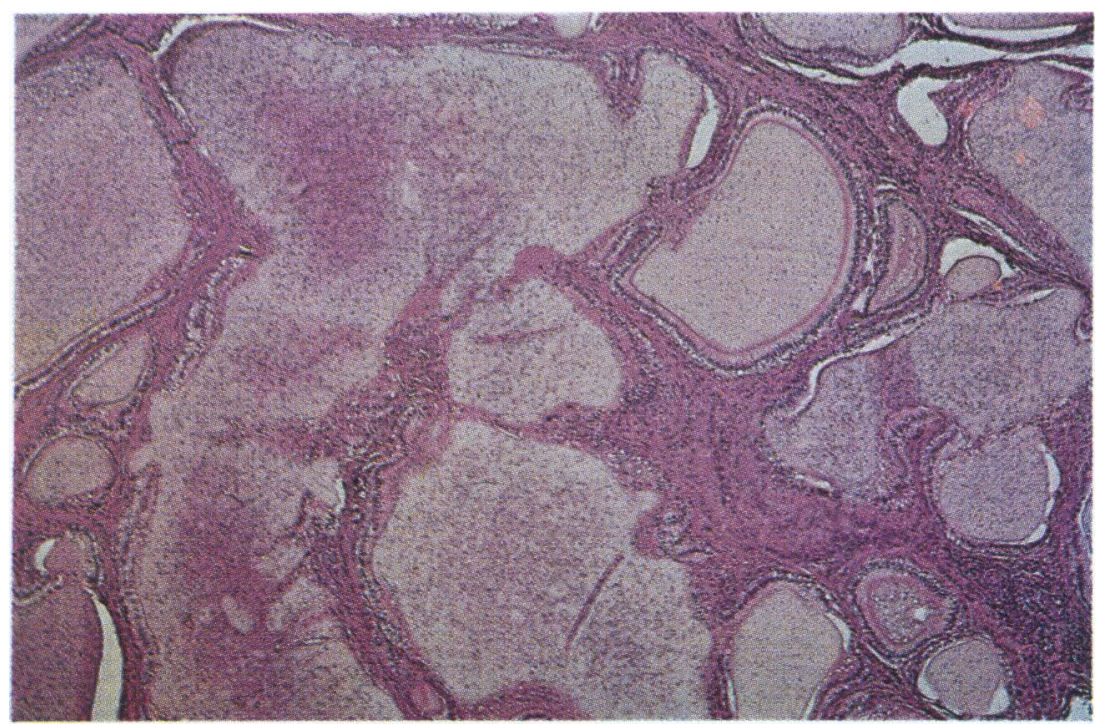

F i g u r e 4. Bull 89. Induced seminal vesiculitis. Interalveolar fibrosis, stagnation of secretion, atrophy of epithelial cells. Interalveolar connections. (HE, $42 \times)$. 


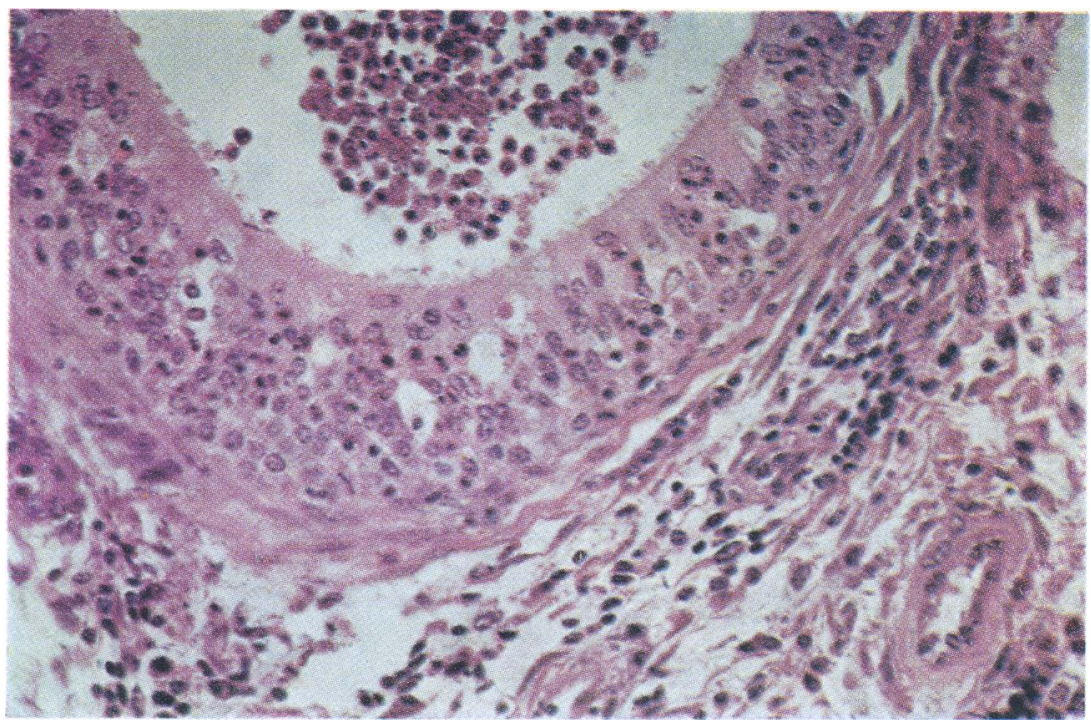

F i g u r e 5. Bull 90. Induced epididymitis. Intraductular cells, mainly eosinophils, occurring also intraepithelially. Interstitial edema, infiltrations mainly of mononuclear cells. Degeneration of blood vessels. ( $\mathrm{HE}, 265 \times$ ).

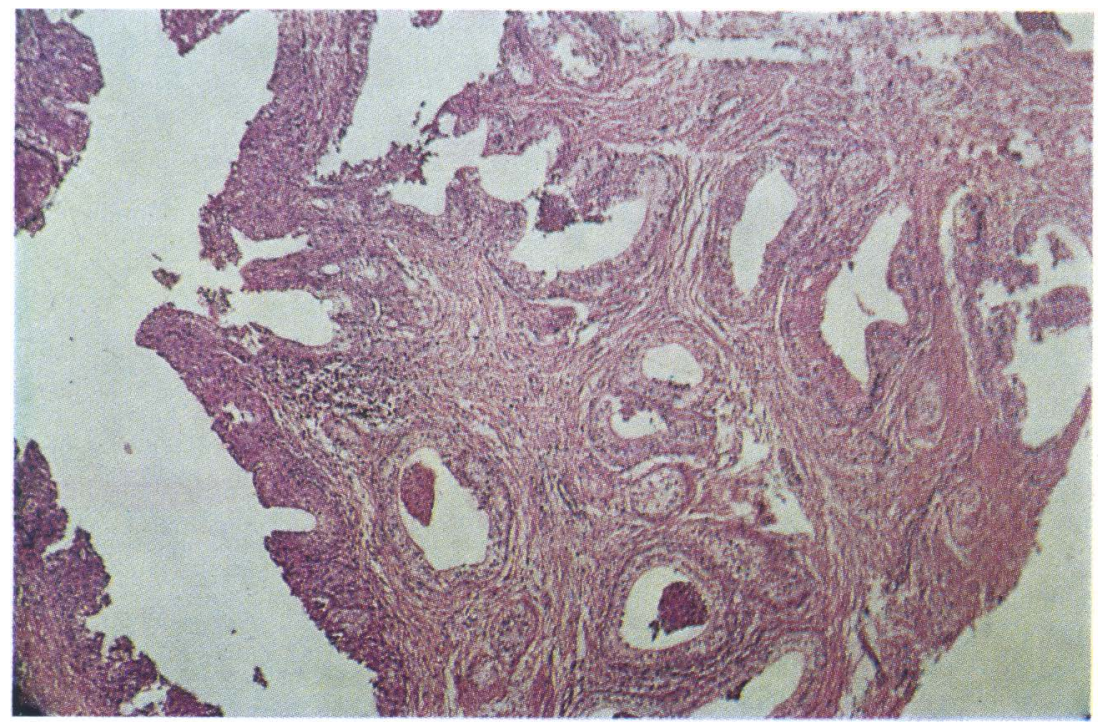

F i g u r e 6. Bull 90. Induced ampullitis. Epithelial hyperplasia, fibrosis, focal accumulations of lymphocytes. (HE, $42 \times$ ). 


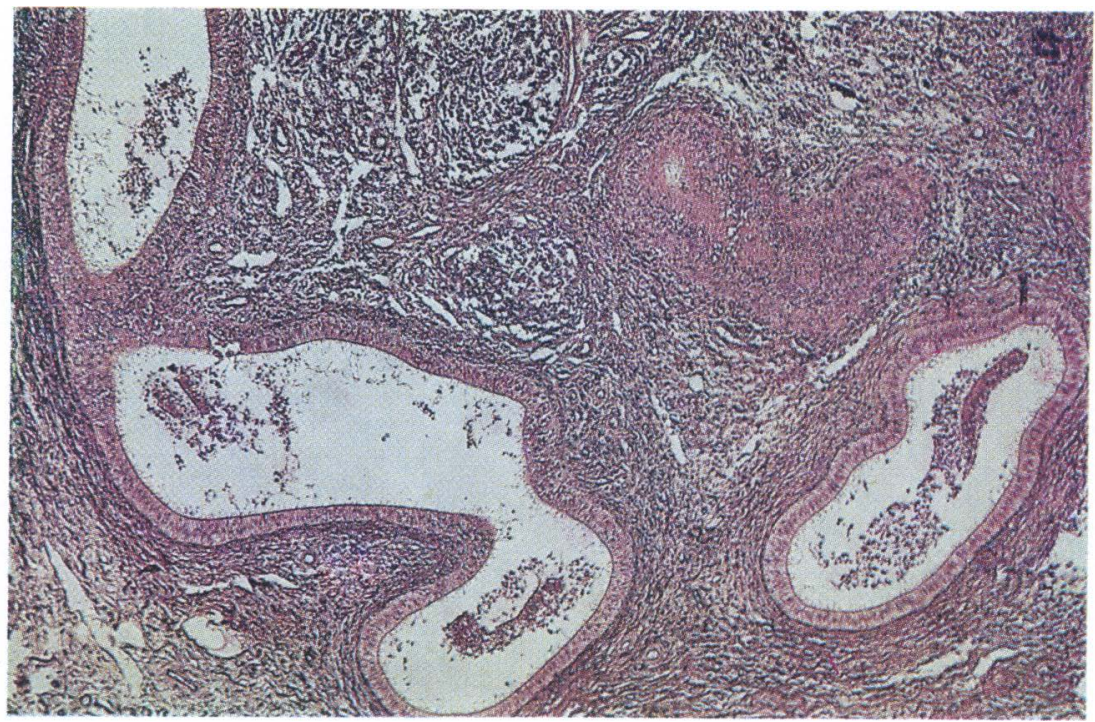

F i g u r e 7. Bull D. Induced epididymitis. Ductular necrosis. Lymphoid hyperplasia. (HE, $42 \times$ ).

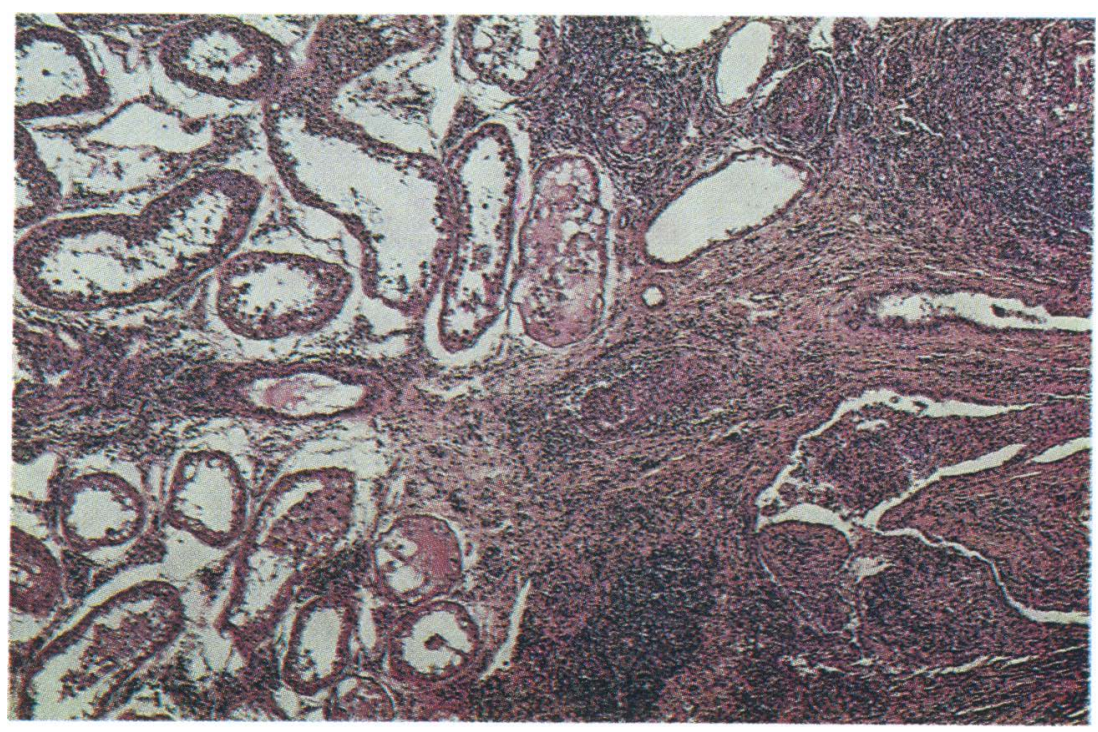

F ig u r e 8. Bull 57. Induced lesions of the rete testis. Lymphoid hyperplasia, fibrosis, necrosis and occlusion of ducts. $(\mathrm{HE}, 42 \times)$. 


\section{Experiment 4. Bull 57}

This animal was inoculated in the preputial cavity with the same culture as used in experiments 2 and 3 and reinoculated 8 months later in the left testis with a total of $10 \mathrm{ml}$ of a $72-\mathrm{hr}$. old uncloned culture of strain " $K$ " with $10^{7}$ viable cells per $\mathrm{ml}$. The bull was slaughtered 3 months after testicular inoculation.

\section{a. Clinical examination and examination of semen}

No clinical symptoms were found until 4 weeks after testicular inoculation when a diffuse swelling in caput epididymidis appeared together with pus cells in the semen. Mycoplasmas were cultured from semen 1 week prior to this and persisted during the remaining period of observation as did the pus cells - though not in great numbers. The epididymal swelling persisted for only 1 month.

\section{b. Examination post mortem}

The left testis had a weight of $690 \mathrm{~g}$ as compared to $460 \mathrm{~g}$ for the right testis. Microscopically, lesions as described in bull 90 were found in the rete testis and epididymis (Fig. 8); although plasma cells were more prominent and eosinophils were not present. The inflammation of the rete testis was predominantly chronic with lymphoid hyperplasia, fibrosis, necrosis, and occlusion of ducts. A chronic, fibrotic and suppurative ampullitis was found. A titer of 2048 was found in serum by the indirect hemagglutination test (Table 1).

\section{Experiments 5 and 6. Bulls 181 and 182}

These animals were inoculated in both vesicular glands with washed mycoplasma cells suspended in unenriched broth. Bull 181 was infected with the " $K$ " strain (108 viable cells in $12 \mathrm{ml}$ of broth) and bull 182 was inoculated similarly with an equally concentrated suspension of PG 11 (type strain of M. bovigenitalium). Both strains were colony cloned at least 3 times. Strain " $K$ " was subcultured 8 times; whereas the passage number of PG 11 is unknown. Both animals were slaughtered after 2 months of observation.

\section{a. Clinical examination and examination of semen}

Three days p.i. the left vesicular gland of bull 181 was enlarged, firm and adherent to the surroundings; a few days later it was enlarged $1 \frac{1}{2}$ times. Thereafter the swelling gradually subsided; although the gland remained larger and firmer than normal. A little swelling appeared in the anterior part of the right gland 3 days p.i. and disappeared within a week. Mycoplasmas were isolated on the 4th day (102 c.f.u. per $\mathrm{ml}$ ), and the semen remained positive with a maximum $\left(2 \times 10^{6}\right.$ c.f.u. per $\left.\mathrm{ml}\right)$ at 2 weeks p.i. The first ejaculates were darkbrown in color, probably due to hemorrhages following the injections; later a typical admixture of pus floccules appeared. 
No clinical symptoms were found in bull 182; the semen remained normal and mycoplasmas were only recovered once, 8 weeks p.i. The hemograms in both bulls were normal throughout the period of observation.

\section{b. Examination post mortem}

The left vesicular gland of bull 181 was covered with fibrous tissue (Fig. 9); secretion appeared honey-like and was occasionally coagulated forming small plugs which protruded from the fibrotic cut surface. Secretion from the right gland was brownish and serum-like in the anterior part; microscopically, fibrosis and epithelial proliferations without cellular infiltration were found in this area. The lesions in the left gland were predominantly fibrotic and hyperplastic, but there were areas with intraalveolar and intraepithelial infiltration of eosinophils.

T a ble 2. Serum titers of bull 181 and bull 182 inoculated with

M. bovigenitalium as measured by indirect hemagglutination.

\begin{tabular}{|c|c|c|c|c|}
\hline \multicolumn{2}{|c|}{ Bull 181} & \multicolumn{2}{|c|}{ Bull 182} & \multirow{3}{*}{$\begin{array}{l}\text { Weeks after } \\
\text { inoculation }\end{array}$} \\
\hline \multicolumn{2}{|c|}{ Antigen } & \multicolumn{2}{|c|}{ Antigen } & \\
\hline $\mathbf{K}$ & PG 11 & PG 11 & $\mathbf{K}$ & \\
\hline 2 & 2 & 8 & 8 & 0 \\
\hline 32 & 32 & 32 & 16 & 2 \\
\hline 16 & 16 & 64 & 16 & 4 \\
\hline 32 & 32 & 64 & 32 & 8 \\
\hline 64 & 8 & 64 & 64 & 9 \\
\hline
\end{tabular}

Note: Bull 181 was inoculated with strain " $K$ ".

Bull 182 was inoculated with strain PG 11.

Mycoplasmas were recovered from both glands and the preputial cavity. A rise in serum titer (from 2 to 32 ) was demonstrated in less than 2 weeks. The titer was not significantly changed throughout the remaining period of observation (Table 2).

No lesions were found in bull 182 (Fig. 9), and mycoplasmas were not recovered. However, a significant rise in serum titer was demonstrated (from 8 to 64) during 4 weeks (Table 2).

\section{RESULTS}

The experiments clearly prove that M. bovigenitalium in bulls may be one of the causes of seminal vesiculitis, ampullitis, epididymitis, and inflammation of the rete testis (Table 3). It seems very likely that the chronic vesiculitis in bull $K$ was caused by 


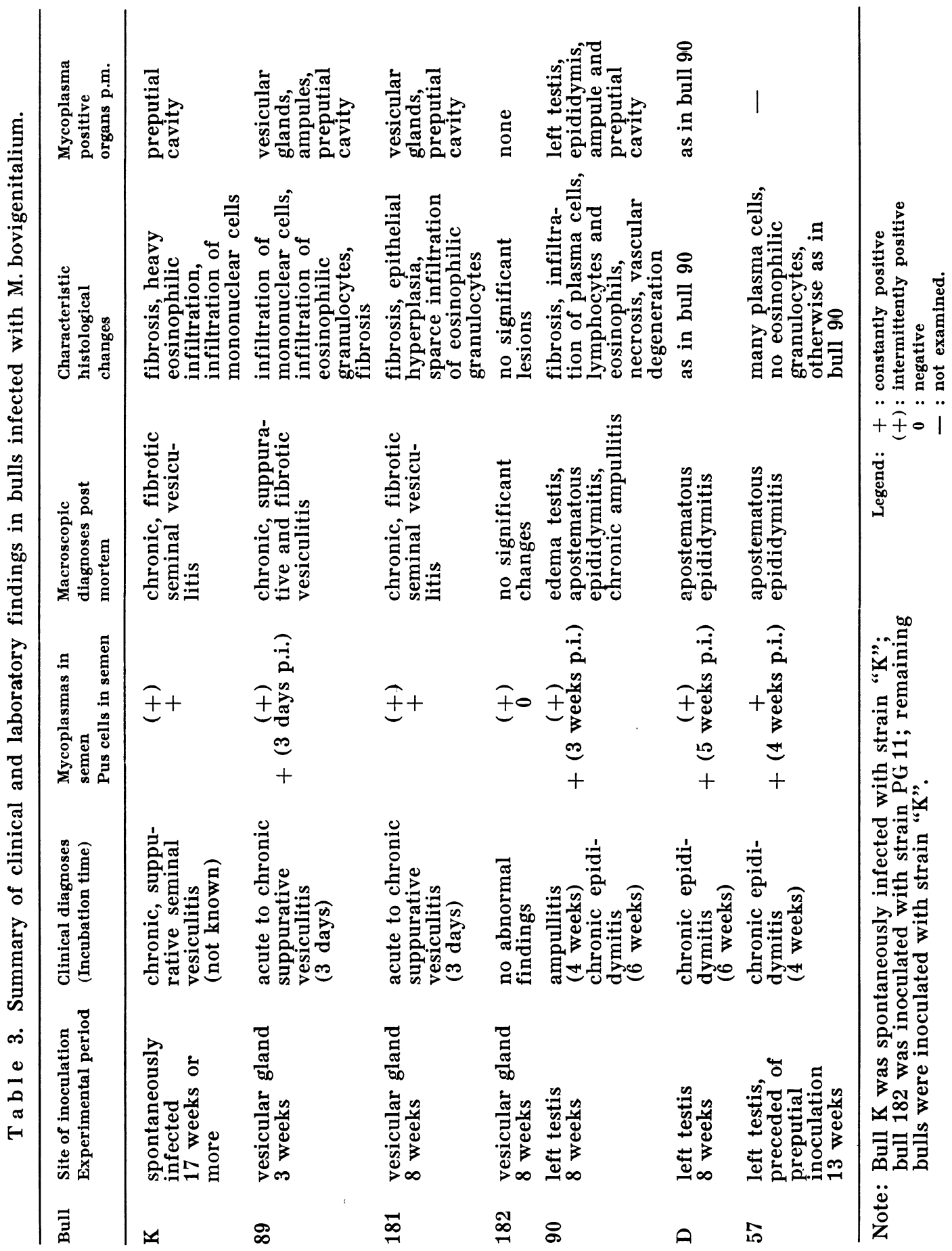


mycoplasmas, since the lesions were of the same type as those induced by experimental infection.

Mycoplasma vesiculitis is characterized by a moderate to marked enlargement of the firmer and sometimes nodular glands. Admixture of cells, even pus floccules are seen in the semen, which may have a brownish color. Sperm morphology appears normal. Mycoplasmas can usually be cultured from semen, but shedding may fluctuate with 1 sample being free of mycoplasmas and the next having $10^{6}$ c.f.u. of mycoplasmas per ml.

The cut surface of the gland is either dry and brownish in color with a sparce secrction presenting itself as honey-like drops occasionally coagulated, forming small protruding plugs, or dry and pale with a thick, yellow, creamy secretion. Histologically, the gland is the site of progressive inflammation with areas of fibrosis, stagnation of secretion, and atrophy of epithelium adjacent to areas with edema and extensive accumulations of eosinophils or to areas with heavy infiltrations of alternate amounts of histiocytes, lymphocytes and plasma cells. Hyaline degene-

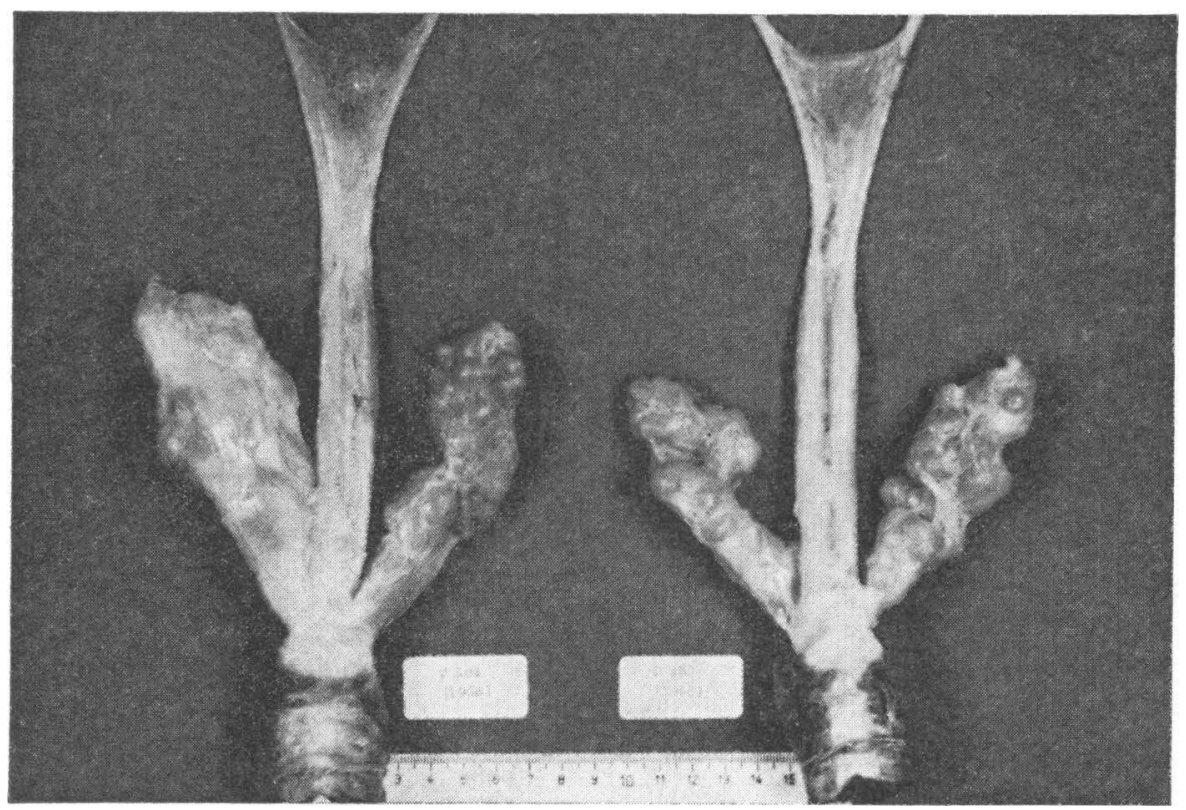

F i g u r e 9. Bulls 181 and 182. Vesicular glands and ampules. Macroscopic changes only in the left vesicular gland of bull 181. Distinct enlargement and capsular fibrosis. 
ration of walls of blood vessels and fibrous tissue, as well as epithelial hyper- and metaplasia, are recognized.

Testicular inoculations caused chronic epididymitis and ampullitis in all 3 experiments. In the spermiogenetic tissue only few and insignificant lesions were found, but a severe lymphoid hyperplasia developed in the rete testis. Clinical symptoms were not observed until 4 to 6 weeks p.i. Subsequently variable numbers of pus cells were present in the semen. Mycoplasmas could only be recovered intermittently. Histologic lesions were similar to those present in the vesicular glands, i.e. a progressive acute and chronic inflammation with a more or less pronounced infiltration of eosinophilic cells.

A preceding preputial infection with $\mathrm{M}$. bovigenitalium did not alter the course of disease, nor were growth factors in enriched nutrient broth or preformed toxins in cultures of importance for development of lesions. A serologic response was generated, although antibodies were formed only to a low titer. A significant rise in antibodies was seen also following inoculation with PG 11, which did not cause clinical or pathological changes.

\section{DISCUSSION AND CONCLUSIONS}

It is evident from the experiments and observations herein reported that it is impossible at this point to make a diagnosis of mycoplasma disease of the genital tract of bulls based on clinical symptoms or routine examinations of semen samples. A species classification is not very helpful as it is still unknown whether some strains are more pathogenic than others within a given species as M. bovigenitalium. Neither do serologic tests appear to be of great value in regard to positive diagnoses solely because the maximum titer usually is low and may be reached within less than 10 days after appearance of clinical symptoms. It may be deduced from Table 1 , bull 57 , that the low titer is not due to a lack of sensitivity of the test as assumed by Parsonson (1970), but simply that the actual amount of antibody is small. However, the great sensitivity of the indirect hemagglutination test implies that a repeated negative serologic test is of value in ruling out a given species of mycoplasma as responsible for the said genital disorders.

Our clinical observations agree with the findings of Al-Aubaidi (1969) and Parsonson. However, it may be deduced from their 
experimental and spontaneous cases of mycoplasma vesiculitis that the organisms may have a greater tendency for canalicular and generalized spreading than observed in our material although the significant lesions were still confined to the genital tract, and largely to the seminal vesicles, testis and epididymis. Eosinophilic cells are not mentioned in the work of Al-Aubaidi, whereas Parsonson observed, on inoculation of $M$. bovigenitalium into the seminal vesicles of 13 bulls, that eosinophils were commonly present in the inflammatory cell population in a high percentage. Very reasonably Parsonson gives this phenomenon great interest and holds that the persistence of mycoplasmas in the genital tract of the experimental bulls provides a constant source of antigen which could then combine with locally produced antibody to form antigen-antibody complexes that attract eosinophils. We shall confine ourselves to say that the mechanism behind the eosinophilic response remains obscure, not knowing whether antibodies are actually present in the tissues, whether they are locally produced, and if present, homologous or heterologous. What is actually known about the phenomenon is that the eosinophilic response has been reported in mastitis (Karbe et al. 1967 and Mosher et al. 1968), in endometritis (Hartmann et al. 1964) and in salpingitis (Hirth et al. 1966) caused by M. agalactiae var. bovis. It has also been reported in mastitis (Ern 1967), and arthritis (Ern $\varnothing$ 1969) caused by M. bovigenitalium. Eosinophils may occur within a few hours in the case of infection of the mammary gland with the former species, which grows rapidly and is uncommon in cattle; whereas the response following infection with $\mathrm{M}$. bovigenitalium is somewhat slower, indicating a quantitative aspect in the reaction. It was recently reported (Mosher 1970) that an immediate eosinophilic skin reaction appeared in cows and pigs intradermally inoculated with purified and concentrated material from M. agalactiae var. bovis consisting of $73 \%$ carbohydrate and $17 \%$ protein.

Finally, considering the interesting phenomenon of eosinophilic infiltration as described in this paper, the attention is drawn to the work of Godal \& Kâresen. (1967) on histological changes in the thyroid of guinea-pigs following intraperitoneal injection of rabbit anti-guinea-pig thyroglobulin immune serum. Within 24 hrs. an acute eosinophilic response developed, succeeded after 5 days by proliferation of histiocytes and lymphocytes and later by a slight fibrosis. Not only is the cellular 
response the same as in the above-mentioned diseases, but even more striking is the resemblance in morphology of the eosinophils which in both cases are somewhat atypical, often having a hypersegmented nucleus with few and poorly stained cytoplasmic granules.

It is interesting to register such similarities in 2 primarily much different diseases. There is every reason to believe that a common pathophysiological mechanism exists, the nature of which is largely an unsolved problem.

\section{REFERENCES}

Al-Aubaidi, J. M.: Bovine Mycoplasma: Purification, characterization, classification, and pathogenicity. Thesis, Cornell University 1969.

Blom, E. \& N. O. Christensen: Congenital absence of the epididymis, ductus deferens or glandula vesicularis (Aplasia segmentalis ductus Wolffii) in the bull. Royal Vet. \& Agric. College, Yearbook 1951, 1-64.

Blom, E. \& H. Ern $\varnothing$ : Mycoplasmosis: Infections of the genital organs of bulls. Acta vet. scand. 1967, 8, 186-188.

Christensen, N. O.: Studies on the agglutinin formation in brucellar infection of the genitals of the bull. Acta path. microbiol. scand. 1948, 25, 202-209.

Ern $\varnothing, H .:$ Mycoplasmosis: Demonstration of pathogenicity of a Danish strain of mycoplasma. Acta vet. scand. 1967, 8, 184-185.

Ern $\varnothing, H .:$ Mycoplasmosis: Experimental inoculation of calves with a Danish strain of Mycoplasma bovigenitalium. Acta vet. scand. 1969, 10, 106-107.

Ernф, H.: Mycoplasmosis: Serology of infections in the genital tract of bulls. Infect. Immunity 1972, 5, 20-23.

Ernф, H., W. N. Plastridge \& M. E. Tourtellotte: Mycoplasma: Isolation from prepuce and semen of bulls. Acta vet. scand. 1967, 8, 123135.

Godal, T. \& R. Kåresen: Induction of thyroiditis in guinea pigs by serum from rabbits immunized with guinea pig thyroglobulin. Acta path. microbiol. scand. 1967, 69, 332-342.

Hartmann, H. A., M. E. Tourtellotte, S. W. Nielsen \& W. N. Plastridge: Experimental bovine uterine mycoplasmosis. Res. Vet. Sci. 1964, 5, 303-310.

Hirth, R. S., S. W. Nielsen \& W. N. Plastridge: Bovine salpingo-oophoritis produced with semen containing a mycoplasma. Path. Vet. 1966, 3, 616-632.

Karbe, E., S. W. Nielsen \& C. F. Helmboldt: Pathologie der experimentellen Mykoplasmen - Mastitis beim Rind. (Pathology of 
experimental mycoplasma mastitis in the cow). Zbl. Vet. Med., B. 1967, 14, 7-31.

Krogsgaard-Jensen, A.: Indirect hemagglutination with mycoplasma antigens: effects of $\mathrm{pH}$ on antigen sensitization of tanned fresh and formalinized sheep erythrocytes. Appl. Microbiol. 1971, 22, $756-759$.

Mosher, A. H.: Patho-biology of a mycoplasmal toxin. Thesis, University of Connecticut 1969. (cit. Vet. Bull. 1970, 40, abstr. no. 2175).

Mosher, A. H., W. N. Plastridge, M. E. Tourtellotte \& C. F. Helmboldt: Effect of toxin in bovine mycoplasmal mastitis. Amer. J. vet. Res. 1968, 29, 517-522.

Parsonson, I. M.: Mycoplasma bovigenitalium: Experimental induction of genital disease in bulls. Thesis, Cornell University 1970.

\section{SAMMENDRAG \\ Mycoplasmose: Genitalvejsinfektioner hos tyre.}

Fra sædprøver af tyren $\mathrm{K}$ med kronisk sædblærebetændelse isoleredes en stamme af Mycoplasma bovigenitalium. Med denne induceredes eksperimentelt hos 2 tyre en sædblærebetændelse af samme type som hos tyr K, karakteriseret ved samtidige akutte og kroniske forandringer. I den akutte fase fandtes kraftige ansamlinger af eosinophile granulocyter $\mathrm{i}$ det interstitielle bindevæv og alveoler, medens der i den kroniske fase sås fibrose, lymphoid og epithelial hyperplasi. Degeneration af bindevæv og karvægge var almindeligt forekommende.

Ved direkte inokulation $i$ testis hos 3 tyre fremkaldtes kronisk epididymitis og ampullitis. De histologiske forandringer var af samme karakter som fundet hos de 3 tyre med sædblærebetændelse.

Der kunne ved indirekte hæmagglutination påvises en specifik, signifikant antistofstigning, men da titrene var lave og maximum hurtigt nået, vil man næppe ret ofte i praksis kunne stille en ætiologisk diagnose på serologisk grundlag.

Der udf $\varnothing$ rtes et sammenlignende fors $\varnothing \mathrm{g}$ med typestammen (PG 11) for M. bovigenitalium. Efter inokulation $\mathrm{i}$ sædblæren fandtes antistofstigning, men der kunne ikke påvises hverken kliniske eller histologiske forandringer.

(Received March 18, 1971).

Reprints may be requested from: E. Blom, State Veterinary Serum Laboratory, Bülowsvej 13, DK-1870 Copenhagen V, Denmark. 